\title{
Proteome Analysis of Cerebrospinal Fluid in Healthy Beagles and Canine Encephalitis
}

\author{
Kozo NAKAMURA ${ }^{1)}$, Taku MIYASHO ${ }^{2)}$, Sachiko NOMURA ${ }^{2)}$, Hiroshi YOKOTA ${ }^{2)}$ and Tetsuya NAKADE)* \\ 1) Department of Small Animal Clinical Sciences, School of Veterinary Medicine, Rakuno Gakuen University, 582 Bunkyodai- \\ Midorimachi, Ebetsu, Hokkaido 069-8501, Japan \\ ${ }^{2}$ Department of Veterinary Biochemistry, School of Veterinary Medicine, Rakuno Gakuen University, 582 Bunkyodai-Midorimachi, \\ Ebetsu, Hokkaido 069-8501, Japan
}

(Received 21 October 2011/Accepted 4 January 2012/Published online in J-STAGE 18 January 2012)

ABSTRACT. We performed proteomics analysis of the cerebrospinal fluid (CSF) of healthy dogs and dogs with meningoencephalitis of unknown etiology (MUE). By comparing two-dimensional electrophoreses (2DE), an upregulated spot was found in MUE dogs. This protein was identified as a neuron-specific enolase (NSE) by analysis with MALDI-TOF mass spectrometry. In comparing dot blots using an antibody against NSE, the NSE levels in the CSF of MUE dogs was significantly higher than that of the controls. NSE is a diagnostic marker of neuroendocrine tumors, brain injury and spinal cord trauma in humans. It seems that the NSE concentration in the CSF is increased by cellular destruction in canine encephalitis. Though elevation of NSE may not be specific in canine encephalitis because the NSE level was increased in other CNS diseases, further study including measurement with serum is necessary.

KEY WORDS: 2DE, canine, CSF, encephalitis, proteome.

doi: 10.1292/jvms.11-0474; J. Vet. Med. Sci. 74(6): 751-756, 2012

Dogs are affected by various diseases of the central nervous system (CNS). However, the origin of some conditions, such as CNS inflammatory disease, is unknown. The development of cures for CNS diseases will require more in-depth investigations to determine the underlying causes. Meningoencephalitis of unknown etiology (MUE) is one of the most common clinical diagnosis in canine inflammatory CNS disease. The terminology meningoencephalitis of unknown etiology is proposed to describe dogs with a CNS inflammatory disease that lacks a histopathological diagnosis [19]. Necrotizing meningoencephalitis (NME), granulomatous meningoencephalomyelitis (GME) and necrotizing leukoencephalitis (NLE) are included in MUE. Because a tissue diagnosis during the lifetime of a patient is difficult in current veterinary medicine, we tend to diagnose patients with MUE until postmortem histopathological examination.

Cerebrospinal fluid (CSF) is the only body fluid that surrounds the brain, and analysis of CSF can provide direct information regarding the physiological condition of the brain. This is therefore often performed as part of the diagnostic process for various neurological diseases. Studies of CSF have been performed in relation to various canine CNS diseases. However, there have been no comprehensive analyses of the canine CSF proteome. In humans, analyses of the CSF proteome have been used to search

\footnotetext{
*Correspondence to: Nakade, T., Department of Small Animal Clinical Sciences, School of Veterinary Medicine, Rakuno Gakuen University, 582 Bunkyodai-Midorimachi, Ebetsu, Hokkaido 069-8501, Japan.

e-mail: tnakade@rakuno.ac.jp

C2012 The Japanese Society of Veterinary Science
}

for diagnostic markers in patients with multiple sclerosis, Guillain-Barré syndrome and Alzheimer's disease [1, 4, $5,11,16,17]$. The search for biomarkers of neurological diseases in dogs will require proteomic analyses of CSF in normal dogs. We aimed to determine a characteristic CSF protein pattern by comparing control and MUE dogs with 2DE. We also compared the level of a protein that showed differential expression in CSF.

\section{MATERIALS AND METHODS}

Sample collection: CSF was taken by cisternal puncture from 15 healthy beagles (age: $4.9 \pm 2.8$; average \pm SD) under general anesthesia and centrifuged at $1,000 \times g$ for $8 \mathrm{~min}$ at $4^{\circ} \mathrm{C}$ to eliminate cells and insoluble material, and then the supernatant fluid was stored at $-70^{\circ} \mathrm{C}$ until analysis.

Twenty-five dogs were diagnosed with MUE based on clinical findings and findings from magnetic resonance imaging (MRI) and routine CSF examinations as follows: (1) focal or multifocal neuroanatomical localization, (2) negative blood and/or CSF infectious disease titers, (3) CSF pleocytosis and/or increasing of protein level (5 cells/ $\mathrm{mm}^{3}$ and/or $25 \mathrm{mg} / \mathrm{d} l$ ), (4) MRI of the brain consistent with focal or multifocal disease (some cases had formed cavitation), (5) fundoscopic and neurological examination consistent with optic neuritis (blindness with normal electroretinogram in the absence of imaging evidence of thalamic or cerebral disease). CSF was taken as described above. The MUE cases comprised ten Pugs, five Shih-Tzus, four Yorkshire Terriers, two Chihuahuas, two Malteses and two Pekingeses (age: $3.0 \pm 2.7$; average $\pm \mathrm{SD}$ ).

Two-dimensional electrophoresis $(2 D E)$ : To concentrate proteins and remove salt, all control samples and some 
encephalitis samples were centrifuged with Amicon Ultra ${ }^{\circledR}$ (Millipore Corporation, Billerica, MA, U.S.A.) at $4^{\circ} \mathrm{C}$. Protein concentration was determined in all concentrated samples by a 2-D Quant kit (GE Healthcare, Buckinghamshire, U.K.).

Isoelectric focusing (IEF) was carried out with a PROTEAN $^{\circledR}$ IEF Cell electrophoresis system (Bio-Rad Laboratories, Hercules, CA, U.S.A.). For analytical runs, $40 \mu \mathrm{g}$ of protein (100 $\mu \mathrm{g}$ for preparative runs) was mixed with a rehydration solution containing $8 \mathrm{M}$ urea, 2\% CHAPS, $0.5 \%$ carrier ampholytes (Bio-Lyte ${ }^{\circledR} 3 / 10$ buffer, Bio-Rad), $18 \mathrm{mM}$ DTT and a trace of bromophenol blue in a total volume of $200 \mu \mathrm{l}$ and applied to immobilizing $\mathrm{pH}$ gradient gels (ReadyStrip $^{\text {TM }}$ IPG Strips, 7 cm, 3-10 NL, Bio-Rad). After passive rehydration for $14 \mathrm{hr}$ at $20^{\circ} \mathrm{C}$, IEF was performed for both analytical and preparative runs as follows: rapid $250 \mathrm{~V}$ for $1 \mathrm{hr}$; linear $8,000 \mathrm{~V}$ for $2 \mathrm{hr}$ and rapid 8,000 $\mathrm{V}$ for $80,000 \mathrm{~V}$-hr. Focused strip gels were reduced by equilibrating for $30 \mathrm{~min}$ in equilibration buffer containing $64.8 \mathrm{mM}$ DTT and then alkylated by equilibrating for $30 \mathrm{~min}$ in 135 $\mathrm{mM}$ iodoacetamide. SDS-PAGE was performed according to the Laemmli method [10], with slight modifications, on $13 \%$ gels at a constant current of $5 \mathrm{~mA} / \mathrm{gel}$ at $4{ }^{\circ} \mathrm{C}$ until the bromophenol blue dye front reached the bottom of the gel. After SDS-PAGE, analytical gels were silver stained (Dodeca $^{\text {TM }}$ Silver Stain Kit, Bio-Rad), and preparative gels were stained with CBB.

In-gel digestion and MALDI-TOF MS analysis: The protein spots observed in preparative gels that corresponded to spots observed in analytical gels were excised and then destained with $50 \mathrm{mM} \mathrm{NH}_{4} \mathrm{HCO}_{3}$ and $50 \%$ methanol. After washing with Milli-Q water, the gel pieces were dehydrated with $50 \mathrm{mM} \mathrm{NH}_{4} \mathrm{HCO}_{3}$ and $50 \%$ acetonitrile (AN) and then completely dehydrated with $100 \%$ AN. Porcine trypsin (50 $n$ g; Promega, Madison, WI, U.S.A.) dissolved in $5 \mu l$ of 50 $\mathrm{mM} \mathrm{NH} \mathrm{HCO}_{3}$ was added to each gel plug along with $5 \mu \mathrm{l}$ of $100 \mathrm{mM}$ Tris-HCl, $\mathrm{pH}$ 8.8. Proteins were digested for 15 $\mathrm{hr}$ at $37^{\circ} \mathrm{C}$, and the resulting peptides were eluted from the gel plugs at room temperature with $50 \mu l$ of $50 \%$ AN/0.1\% trifluoroacetic acid (TFA) and dried in a vacuum centrifuge down to a total volume of $20 \mu \mathrm{l}$. The samples were then purified by binding them to a pipette tip (ZipTip ${ }^{\circledR}$, Millipore Corporation) followed by elution with $50 \%$ AN/0.1\% TFA and $90 \%$ AN/ $0.1 \%$ TFA directly onto the MALDI target. Immediately after samples were applied to the target, $0.5 \mu \mathrm{l}$ of 25\% $\alpha$-cyano-4-hydroxycinnamic acid (Bruker Daltonics, Bremen, Germany), 50\% AN and 0.1\% TFA was stratified and mixed with each sample on the MALDI target.

Peptide mass fingerprint spectra were recorded by MALDI-TOF MS (Autoflex ${ }^{\circledR}$, Bruker Daltonics). The proteins were identified from the mass spectrometry data using the Mascot search program (www.matrixscience.com). Database search results were manually checked by comparison with the nominal mass and calculated $\mathrm{pI}$ value. The protein spot that showed differential expression between the control and encephalitis dogs was excised from the 2DE gels and analyzed by the same method.

2DE Western blotting (WB): Control and MUE CSFs

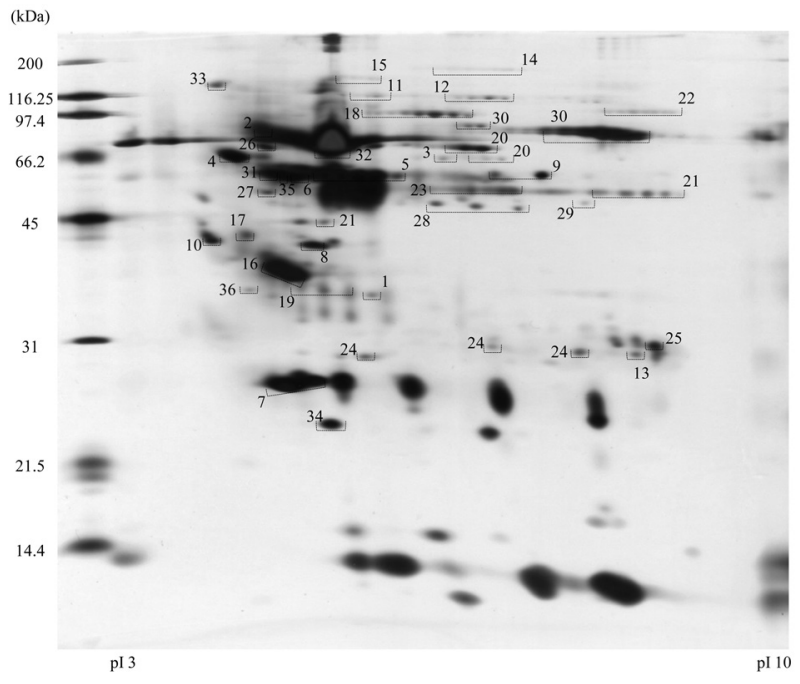

Fig. 1. 2DE map of canine CSF proteins. Protein spots are numbered according to the Mascot search results. Proteins were electrofocused in the first dimension on IPG ReadyStrips $(11 \mathrm{~cm}$, 3-10 NL), and after 2DE, the resultant gels were silver stained.

were separated by an isoelectric electrophoresis system (PROTEAN ${ }^{\circledR}$ IEF Cell, Bio-Rad). Ten micrograms of CSF proteins were mixed with the rehydration solution in a total volume of $125 \mu \mathrm{l}$ and applied to immobilizing $\mathrm{pH}$ gradient gels (ReadyStrip ${ }^{\mathrm{TM}}$ IPG Strips, $7 \mathrm{~cm}, 3-10$ NL, Bio-Rad). After passive rehydration for $14 \mathrm{hr}$ at $20^{\circ} \mathrm{C}$, IEF was performed as follows: rapid $250 \mathrm{~V}$ for $30 \mathrm{~min}$; linear 4,000 V for $1 \mathrm{hr}$ and rapid 4,000 V for 20,000 V-hr. Focused strip gels were reduced by equilibrating for $30 \mathrm{~min}$ in equilibration buffer containing $64.8 \mathrm{mM}$ DTT and then alkylated by equilibrating for $30 \mathrm{~min}$ in $135 \mathrm{mM}$ iodoacetamide. SDSPAGE was performed on $10 \%$ gels at a constant current of 3 $\mathrm{mA} / \mathrm{gel}$ at $4^{\circ} \mathrm{C}$ until the bromophenol blue dye front reached the bottom of the gel, and then transferred onto PVDF membranes (ATTO, Tokyo, Japan).

The membranes were blocked with $2.5 \%$ skim milk in PBS. WB analysis was performed using mouse anti-neuron specific enolase monoclonal antibody (diluted at 1:100; GenWay Biotech, San Diego, CA, U.S.A.) and HRP-conjugated anti-mouse IgG antibody (1:10,000; Pierce Biotechnology, Rockford, IL, U.S.A.). Immunoreactions on the membranes were detected using ECL ${ }^{\mathrm{TM}}$ Western blotting detection reagents (GE Healthcare) and scanned with an Ez-Capture II imaging system (ATTO).

Dot blotting: Ten microliters of CSF samples and $10 \mu \mathrm{l}$ of human recombinant NSE (diluted at 1:200-20,000; ATGen, Sung Nam, Kyung Ki Do, South Korea) were spotted on PVDF membranes using Immunodot ${ }^{\circledR}$ (ATTO). Antigenantibody reactions were performed as described above with same the antibodies and same concentrations. Immunoreactive spots on the membranes were detected using ECL ${ }^{\mathrm{TM}}$ Western blotting detection reagents (GE Healthcare) and scanned with an Ez-Capture II imaging system (ATTO). Quantification of spots was performed using CS Analyzer 
Table 1. Canine CSF proteins identified in this study

\begin{tabular}{|c|c|c|c|c|c|}
\hline No. ${ }^{\text {a) }}$ & Protein identification result ${ }^{\mathrm{b})}$ & Score $^{\mathrm{c})}$ & $\mathrm{pI}^{\mathrm{d})}$ & $\begin{array}{l}\% \text { Sequence } \\
\text { coverage }{ }^{\mathrm{e}}\end{array}$ & $\begin{array}{c}\text { Nominal } \\
\text { mass }^{\mathrm{f}}\end{array}$ \\
\hline 1 & Albumin & 78 & 5.36 & 16 & 67857 \\
\hline 2 & Alpha-1B-glycoprotein precursor (Alpha-1-B glycoprotein) & 203 & 5.38 & 41 & 56264 \\
\hline 3 & Alpha-2-antiplasmin precursor (Alpha-2-plasmin inhibitor) (Alpha-2-PI) (Alpha-2-AP) & 102 & 6.68 & 31 & 55147 \\
\hline 4 & Alpha-2-HS-glycoprotein precursor (Fetuin-A) (Alpha-2-Z-globulin) (Ba-alpha-2-glycoprotein) & 70 & 5.64 & 24 & 39729 \\
\hline 5 & Angiotensinogen precursor & 139 & 5.9 & 32 & 53578 \\
\hline 6 & Antithrombin-III precursor (ATIII) & 102 & 6.58 & 36 & 53712 \\
\hline 7 & Apolipoprotein A-I precursor (Apo-AI) (ApoA-I) & 191 & 5.28 & 75 & 30163 \\
\hline 8 & Apolipoprotein A-IV precursor (Apo-AIV) (ApoA-IV) & 206 & 5.56 & 56 & 46304 \\
\hline 9 & Beta-2-glycoprotein 1 precursor & 229 & 8.51 & 52 & 39689 \\
\hline 10 & Clusterin precursor & 100 & 5.65 & 35 & 52327 \\
\hline 11 & Complement $\mathrm{C} 3$ precursor & 110 & 6.95 & 15 & 175356 \\
\hline 12 & $\begin{array}{l}\text { Complement factor B precursor (C3/C5 convertase) (Properdin factor B) (Glycine-rich beta } \\
\text { glycoprotein) (GBG) (PBF2) }\end{array}$ & 143 & 7.18 & 34 & 87635 \\
\hline 13 & Complement factor D precursor (C3 convertase activator) (Properdin factor D) (Adipsin) & 138 & 9.27 & 44 & 31951 \\
\hline 14 & Complement factor $\mathrm{H}$ precursor $(\mathrm{H}$ factor 1$)$ & 119 & 6.28 & 18 & 101834 \\
\hline 15 & Contactin 1 isoform 2 precursor isoform 1 & 77 & 5.69 & 16 & 112693 \\
\hline 16 & Full=Apolipoprotein E; Short=Apo-E & 149 & 5.2 & 40 & 35332 \\
\hline 17 & $\begin{array}{l}\text { Full=SPARC; AltName: Full=Secreted protein acidic and rich in cysteine; AltName: } \\
\text { Full=Osteonectin; Short=ON; AltName: Full=Basement-membrane protein 40; Short=BM-40; } \\
\text { Flags: Precursor }\end{array}$ & 83 & 4.71 & 33 & 35446 \\
\hline 18 & Gelsolin precursor (Actin-depolymerizing factor) (ADF) (Brevin) (AGEL) & 160 & 6.3 & 38 & 81353 \\
\hline 19 & Haptoglobin heavy chain, $\mathrm{HpH}$ chain & 110 & 5.8 & 51 & 27269 \\
\hline 20 & Hemopexin & 131 & 6.88 & 38 & 52047 \\
\hline 21 & Hypothetical protein XP_533132 & 108 & 5.24 & 38 & 42053 \\
\hline 22 & Immunoglobulin gamma heavy chain B & 126 & 8.52 & 29 & 52553 \\
\hline 23 & Immunoglobulin gamma heavy chain $\mathrm{C}$ & 114 & 6.16 & 31 & 52779 \\
\hline 24 & $\begin{array}{l}\text { Immunoglobulin lambda-like polypeptide } 1 \text { precursor (Immunoglobulin-related } 14.1 \text { protein) } \\
\text { (Immunoglobulin omega polypeptide) (Lambda 5) (CD179b antigen) }\end{array}$ & 86 & 8.84 & 52 & 15118 \\
\hline 25 & Kallikrein 6 precursor (Protease M) (Neurosin) (Zyme) (SP59) & 114 & 7.57 & 35 & 27747 \\
\hline 26 & Kininogen 1 & 187 & 5.58 & 44 & 49400 \\
\hline 27 & Leucine-rich alpha-2-glycoprotein 1 & 104 & 6.17 & 35 & 38390 \\
\hline 28 & Pigment epithelium-derived factor & 119 & 8.69 & 46 & 44293 \\
\hline 29 & $\begin{array}{l}\text { Procollagen C-proteinase enhancer protein precursor (PCPE) (Type I procollagen COOH-termi- } \\
\text { nal proteinase enhancer) (Type } 1 \text { procollagen C-proteinase enhancer protein) }\end{array}$ & 123 & 6.82 & 37 & 49353 \\
\hline 30 & Serotransferrin precursor (Transferrin) (Siderophilin) (Beta-1-metal binding globulin) & 186 & 6.07 & 31 & 80155 \\
\hline 31 & Serpin peptidase inhibitor, clade A (alpha-1 antiproteinase, antitrypsin), member 1 & 83 & 5.58 & 32 & 46505 \\
\hline 32 & Serum albumin precursor & 128 & 5.52 & 45 & 70556 \\
\hline 33 & SPARC-like protein 1 precursor (High endothelial venule protein) (Hevin) (MAST 9) & 107 & 4.61 & 38 & 70706 \\
\hline 34 & Transthyretin precursor (Prealbumin) (TBPA) (TTR) (ATTR) & 82 & 6.42 & 51 & 15972 \\
\hline 35 & Vitamin D-binding protein precursor (DBP) (Group-specific component) (Gc-globulin) (VDB) & 91 & 5.2 & 31 & 54536 \\
\hline 36 & Zinc-alpha-2-glycoprotein precursor (Zn-alpha-2-glycoprotein) (Zn-alpha-2-GP) & 144 & 4.81 & 52 & 36060 \\
\hline
\end{tabular}

a) Numbers correspond to spot numbers in Fig. 1. b) Proteins identified by Mascot search. c) The protein score is $-10 * \log (\mathrm{P})$, where $\mathrm{P}$ represents the probability that the observed match is a random event. Protein scores greater than 67 are significant $(P<0.05)$. d) The isoelectric point expected for a protein with the sequence returned by the database search. e) Refers to the percent of the protein sequence identified by mass spectra. f) The nominal mass is obtained by summing the integer masses of the most abundant naturally occurring stable isotopes of the elements constituting the protein.

3.0 (ATTO). The multiplication value was calculated from the quantity of the luminescence and the area by CS Analyzer. We made a calibration curve from the multiplication value of the luminescence of the recombinant NSE and calculated the NSE concentration. Differences in concentration between the control group and the MUE group were subjected to the Mann-Whitney U test. A $P$ value $<0.05$ was considered significant.

\section{RESULTS}

$2 D E$ : Ten CSF samples were prepared from healthy beagles, the proteins were separated by $2 \mathrm{DE}$ and the resultant gels were silver-stained. A total of 134 protein spots were detected on each gel. From these 134 spots, a total of 97 proteins were identified by MALDI-TOF MS and Mascot searching (Fig. 1). The 97 proteins that were identified were classified into 36 classes, as shown in Table 1. Each of the proteins identified in this study were found in all of the con- 

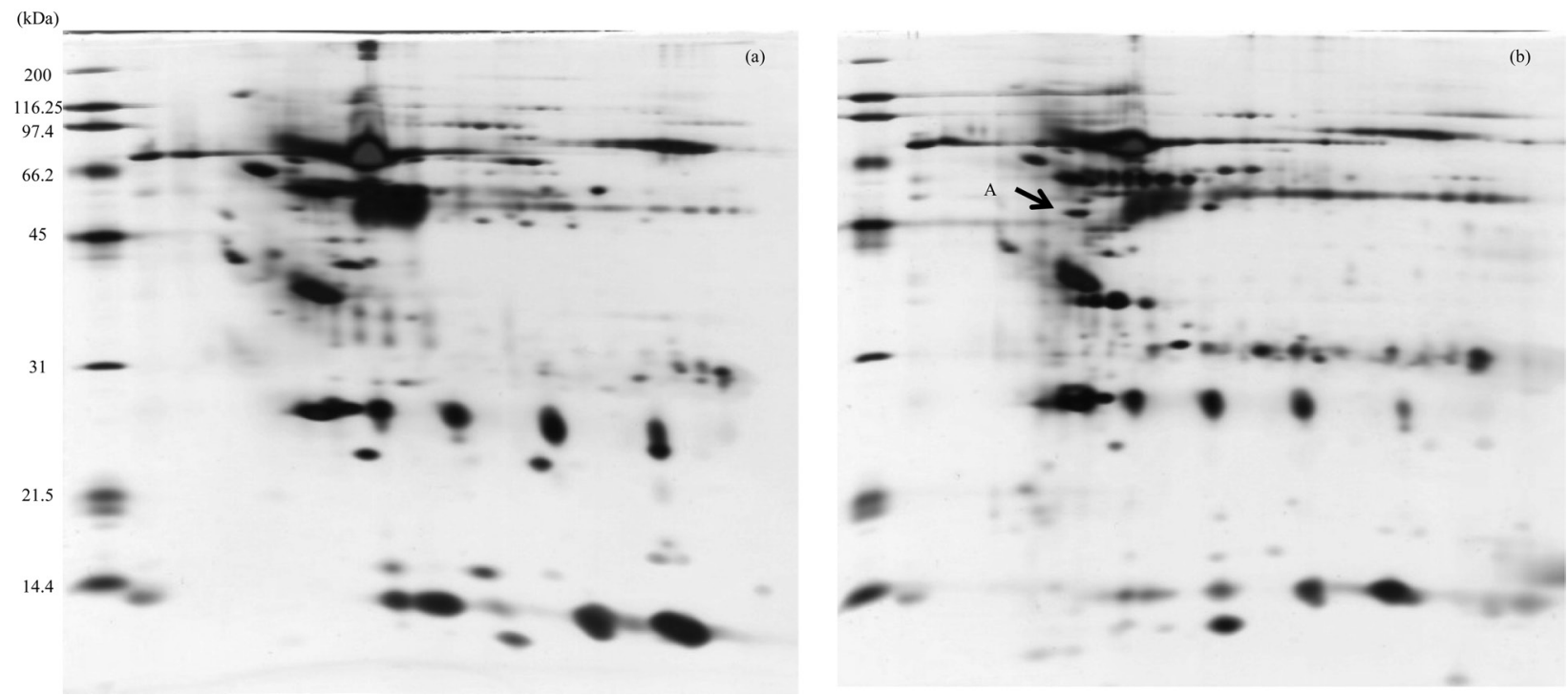

Fig. 2. Control (a) and MUE subject (b) 2DE. Some upregulated spots were detected in MUE subject CSF. Spot A was upregulated in all MUE animal CSFs.
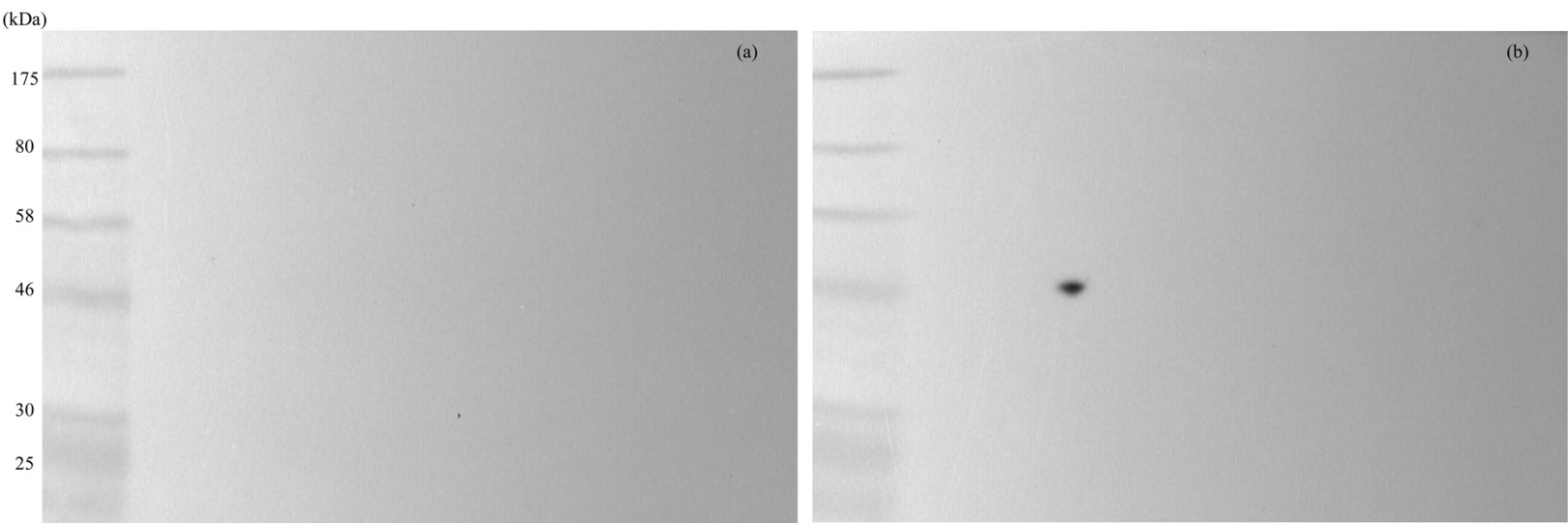

Fig. 3. Result of 2DE-WB. The immunoreactive spot was detected as a unique spot in MUE subject CSFs (b). This spot was consistent with the 2DE gels.

trol CSF samples.

Typical silver-stained 2DE gels of CSF from diseased animals compared with the control group are shown in Fig. 2a and $2 \mathrm{~b}$. Some protein spots were found to differ significantly in the gels between the two groups. Spot A was upregulated in all diseased animals as compared with the controls.

MALDI-TOF MS analysis: The results of the PMF spectra analysis of spot A are shown in Table 2. The spot was identified as a canine neuron-specific enolase. The top score and sequence coverage were 214 and $56 \%$. The nominal mass and $\mathrm{pI}$ values of NSE were 47,499 and 4.98. These data corresponded with the $2 \mathrm{DE}$ gels.

$2 D E-W B$ : The results of $2 \mathrm{DE}-\mathrm{WB}$ are shown in Fig. 3. The spot was detected in the same position on $2 \mathrm{DE}$ gels. The spot was observed as only one spot.

Dot blotting: The NSE level in the MUE group was significantly higher than that in the control group $(P<0.01)$ (Fig. 4). The mean value in the control group was $0.84 \mathrm{ng} / 10$ $\mu l$, and in the MUE group, it was $3.62 \mathrm{ng} / 10 \mu l$. The ROC curve is shown in Fig. 5. When the cutoff value was set at $2.00 \mathrm{ng} / 10 \mu \mathrm{l}$, the diagnostic sensitivity and specificity of the assay for MUE were 96 and 93\%, respectively.

\section{DISCUSSION}

In this study, a clear 2DE protein map was obtained by concentrating and desalting CSF samples from beagles using centrifugal filters. Many proteomic analyses of human CNS diseases involve sample desalting using acetone or trichloroacetic acid precipitation $[1,2,16,17]$. In our study, desalting and concentration of small sample volumes was possible using centrifugal filters. In many cases, only 
Table 2. Tryptic peptides of a common spot in patient CSFs and identified as canine neuronspecific enolase by MALDI-TOF MS analysis

\begin{tabular}{cccl}
\hline Start-End & Observed & Mr(calc) & Sequence \\
\hline $16-28$ & 1380.6731 & 1379.7045 & R.GNPTVEVDLHTAK.G \\
$33-50$ & 1804.9449 & 1803.9366 & R.AAVPSGASTGIYEALELR.D \\
$65-89$ & 2592.3311 & 2591.3806 & K.AVDHINTTIAPALISSGLSVVEQEK.L \\
$106-120$ & 1519.8061 & 1518.8228 & K.FGANAILGVSLAVCK.A \\
$163-179$ & 1938.9849 & 1937.9743 & K.LAMQEFMILPVGAESFR.D \\
$203-228$ & 2702.2395 & 2701.3082 & K.DATNVGDEGGFAPNILENSEALELVK.E \\
$240-253$ & 1544.7983 & 1543.7817 & K.IVIGMDVAASEFHR.D \\
$270-285$ & 1858.9381 & 1857.9261 & R.YITGDQLGALYQDFVR.D \\
$286-306$ & 2483.088 & 2482.0965 & R.DYPVVSIEDPFDQDDWAAWSK.F \\
$307-326$ & 2102.123 & 2101.1056 & K.FTANVGIQIVGDDLTVTNPK.R \\
$344-358$ & 1617.806 & 1616.8192 & K.VNQIGSVTEAIQACK.L \\
$359-372$ & 1583.7691 & 1582.7674 & K.LAQENGWGVMVSHR.S \\
$373-394$ & 2353.1663 & 2352.1519 & R.SGETEDTFIADLVVGLCTGQIK.T \\
$413-422$ & 1160.4889 & 1159.5357 & R.IEEELGDEAR.F \\
\hline
\end{tabular}

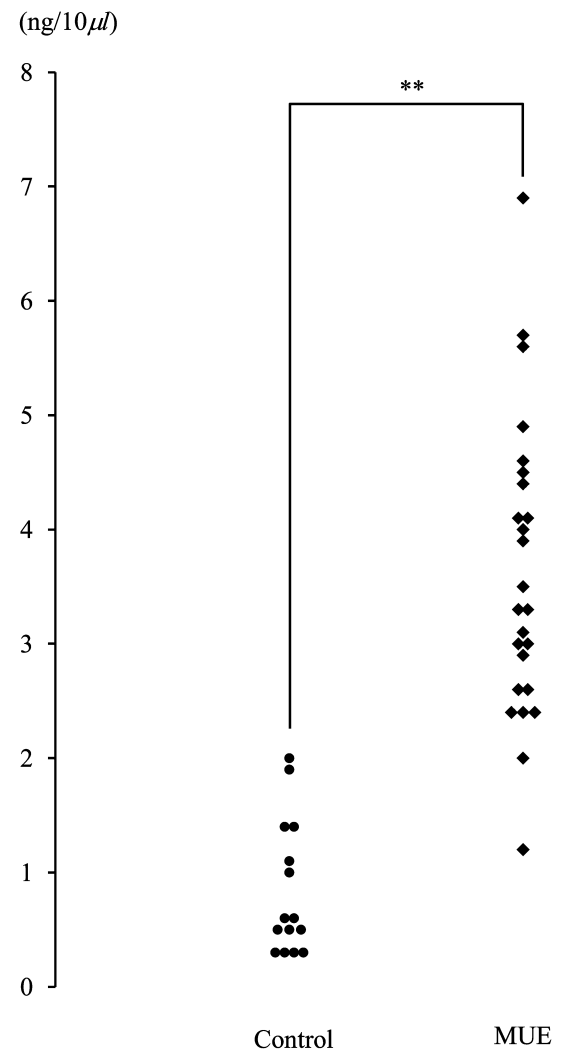

Fig. 4. Concentrations of NSE in cerebrospinal fluid of MUE subjects and in the control group. NSE concentrations of MUE subjects were significantly higher than those of the control group.

$100-500 \mu l$ of CSF can be collected from small animals; therefore, the use of centrifugal filters for sample desalting would be useful for proteome analyses in dogs. Because proteins of less than $3 \mathrm{kDa}$ are removed with the salts using

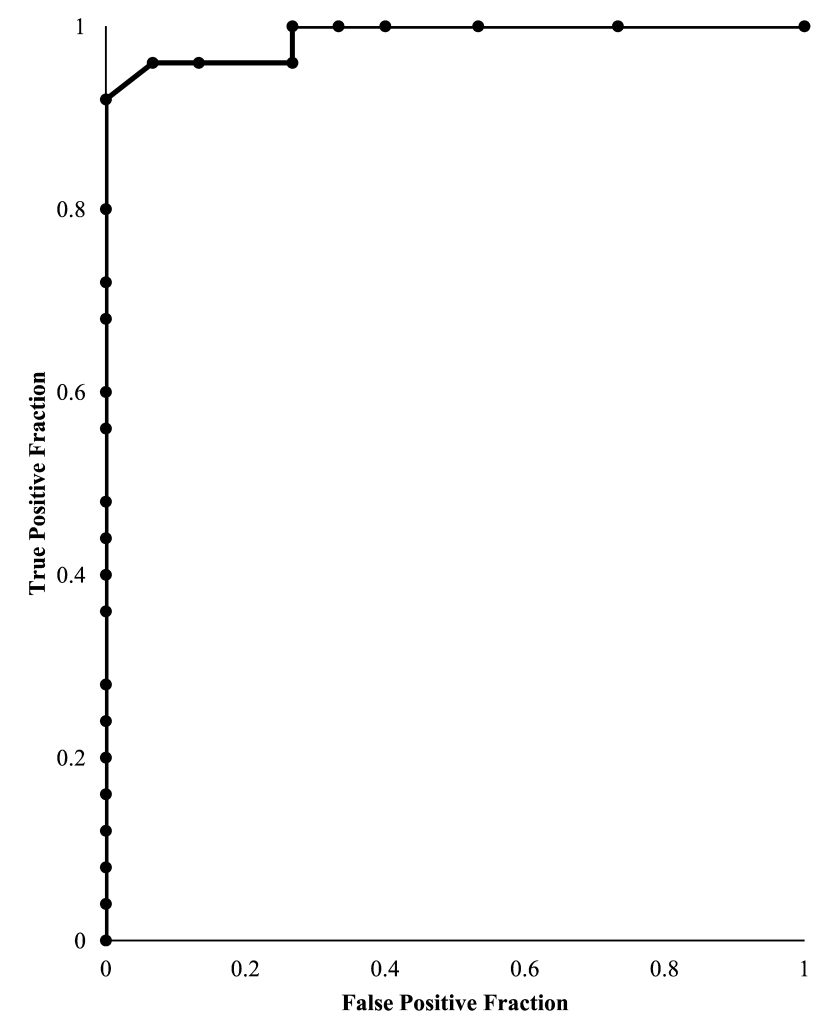

Fig. 5. The ROC curve of the NSE level in CSF. The area of under curve (AUC) was 0.9983

these filters, all proteins could not be analyzed in our study. However, many of the proteins in canine CSF that we identified after centrifugal filter desalting have been identified in 2DE studies in humans and other animals $[2,7,8]$.

Neuron-specific enolase (NSE) is known as a biomarker of CNS disorders, for example, ischemia, head trauma, spinal cord injury and some of tumors, in humans $[3,6,9,12$, 
$13,15]$. NSE is found in neurons and neuroendocrine cells. In present study, the concentration of NSE of healthy dogs was higher than that found in a previous report [14]. This is likely due to the difference in methodology and age of the control group. In humans, there is evidence that the NSE concentration in the CSF rises with age [18]. In the previous report, the dogs were 1-13 months old [14]. In the present study, the age of the healthy dogs was 2-9 years old with an average age of $4.9 \pm 2.8$ years old. Also, the two dogs that showed the highest NSE concentrations in the control group were 9 years old. It seems that the NSE concentration rises in canine CSF according to age, as in humans.

Though MUE dogs were generally younger than healthy dogs, NSE was elevated in the canine CSF in conjunction with the inflammation. Because NSE is usually present in a nerve cell, it is possible that NSE leaked as a result of neuronal destruction. In previous report, even GM1 gangliosidosis increased, so an increasing NSE level may not be specific in encephalitis [14]. Also, we used only beagles as a healthy dog group in this study. It will be necessary to evaluate measurement of NSE with various dog species and at different age. In humans, NSE is measured as a serum marker. We will examine the measurement of serum NSE concentration in dogs. In the present study, we only compared healthy dogs to MUE dogs, so future studies are required to measure the NSE concentrations of the CSF of dogs that have been histopathologically diagnosed with NME, GME or NLE, in addition to other inflammatory disorders, trauma, stroke and brain tumors.

\section{REFERENCES}

1. Bai, S., Liu, S., Guo, X., Qin, Z., Wang, B., Li, X., Qin, Y. and Liu, Y. H. 2009. Proteome analysis of biomarkers in the cerebrospinal fluid of neuromyelitis optica patients. Mol. Vis. 15: 1638-1648. [Medline]

2. Brenn, A., Karger, A., Skiba, M., Ziegler, U. and Groschup, M. H. 2009. A comprehensive proteome map of bovine cerebrospinal fluid. Proteomics 9: 5199-5205. [Medline] [CrossRef]

3. Carney, D. N., Marangos, P. J., Ihde, D. C., Bunn, P. A. Jr., Cohen, M. H., Minna, J. D. and Gazdar, A. F. 1982. Serum neuron-specific enolase: a marker for disease extent and response to therapy of small-cell lung cancer. Lancet 1: 583-585. [Medline] [CrossRef]

4. Castaño, E. M., Roher, A. E., Esh, C. L., Kokjohn, T. A. and Beach, T. 2006. Comparative proteomics of cerebrospinal fluid in neuropathologically confirmed Alzheimer's disease and non-demented elderly subjects. Neurol. Res. 28: 155-163. [Medline] [CrossRef]

5. D’Aguanno, S., Barassi, A., Lupisella, S., D’eril, G. M., Del Bocci, P., Pieragostino, D., Pallotti, F., Carelli, V., Valentino, M. L., Liguori, R., Avoni, P., Bernardini, S., Gambi, D., Urbani, A. and Federici, G. 2008. Differential cerebro spinal fluid proteome investigation of Leber hereditary optic neuropathy (LHON) and multiple sclerosis. J. Neuroimmunol. 193: 156160. [Medline] [CrossRef]
6. Dauberschmidt, R., Marangos, P. J., Zinsmeyer, J., Bender, V., Klages, G. and Gross, J. 1983. Severe head trauma and the changes of concentration of neuron-specific enolase in plasma and in cerebrospinal fluid. Clin. Chim. Acta 131: 165-170. [Medline] [CrossRef]

7. Finehout, E. J., Franck, Z. and Lee, K. H. 2004. Towards twodimensional electrophoresis mapping of the cerebrospinal fluid proteome from a single individual. Electrophoresis 25: 2564-2575. [Medline] [CrossRef]

8. Goldman, D., Merril, C. R. and Ebert, M. H. 1980. Two-dimensional gel electrophoresis of cerebrospinal fluid proteins. Clin. Chem. 26: 1317-1322. [Medline]

9. Hashimoto, K., Gotoh, Y. and Tada, K. 1986. Serum neuronspecific enolase as a marker useful for monitoring the effectiveness of therapy in patients with neuroblastoma-as compared with urinary catecholamine metabolites. Tohoku J. Exp. Med. 149: 25-30. [Medline] [CrossRef]

10. Laemmli, U. K. 1970. Cleavage of structural proteins during the assembly of the head of bacteriophage T4. Nature 227: 680-685. [Medline] [CrossRef]

11. Lehmensiek, V., Süssmuth, S. D., Brettschneider, J., Tauscher, G., Felk, S., Gillardon, F. and Tumani, H. 2007. Proteome analysis of cerebrospinal fluid in Guillain-Barré syndrome (GBS). J. Neuroimmunol. 185: 190-194. [Medline] [CrossRef]

12. Oishi, S. and Sato, T. 1988. Elevated serum neuron-specific enolase in patients with malignant pheochromocytoma. Cancer 61: 1167-1170. [Medline] [CrossRef]

13. Pouw, M. H., Hosman, A. J., van Middendorp, J. J., Verbeek, M. M., Vos, P. E. and van de Meent, H. 2009. Biomarkers in spinal cord injury. Spinal Cord 47: 519-525. [Medline] [CrossRef]

14. Satoh, H., Yamato, O., Asano, T., Yonemura, M., Yamauchi, T., Hasegawa, D., Orima, H., Arai, T., Yamasaki, M. and Maede, Y. 2007. Cerebrospinal fluid biomarkers showing neurodegeneration in dogs with GM1 gangliosidosis: possible use for assessment of a therapeutic regimen. Brain Res. 1133: 200-208. [Medline] [CrossRef]

15. Selaković, V. 2003. Neuron-specific enolase in cerebrospinal fluid and plasma of patients with acute ischemic brain disease. Med. Pregl. 56: 326-332. [Medline] [CrossRef]

16. Yang, Y., Liu, S., Qin, Z., Cui, Y., Qin, Y. and Bai, S. 2009. Alteration of cystatin $C$ levels in cerebrospinal fluid of patients with Guillain-Barré Syndrome by a proteomical approach. Mol. Biol. Rep. 36: 677-682. [Medline] [CrossRef]

17. Yang, Y. R., Liu, S. L., Qin, Z. Y., Liu, F. J., Qin, Y. J., Bai, S. M. and Chen, Z. Y. 2008. Comparative proteomics analysis of cerebrospinal fluid of patients with Guillain-Barré syndrome. Cell. Mol. Neurobiol. 28: 737-744. [Medline] [CrossRef]

18. van Engelen, B. G., Lamers, K. J., Gabreels, F. J., Wevers, R. A., van Geel, W. J. and Borm, G. F. 1992. Age-related changes of neuron-specific enolase, S-100 protein, and myelin basic protein concentrations in cerebrospinal fluid. Clin. Chem. 38: 813-816. [Medline]

19. Zarfoss, M., Schatzberg, S., Venator, K., Cutter-Schatzberg, K., Cuddon, P., Pintar, J., Weinkle, T., Scarlett, J. and Delahunta, A. 2006. Combined cytosine arabinoside and prednisone therapy for meningoencephalitis of unknown aetiology in 10 dogs. J. Small Anim. Pract. 47: 588-595. [Medline] [CrossRef] 